\title{
The Human Rights Commission of Ethiopia:Challenges and Prospects in Promoting and Protecting Human Rights
}

\author{
Adane Mengist \\ Department of Civics and Ethical Studies, Debre Markos University
}

\begin{abstract}
Since 2018, Ethiopia is the leading country, with more than two million numbers of internally displaced peoples (IDP) from different parts of the country. Public demonstrations began around 2016 in Oromia and Amhara regional states are continued which pave the way for ethnic clashes and atrocities, and this worsen the situation of human rights in the country. It is difficult to get information about the situation of human rights in Ethiopia. The incumbent government threatened local civil societies and denied access to information for international human right organizations. The objective of this paper is to assess the challenges and opportunities of the Ethiopian Human Right Commission in its role of promoting and protection of human rights. To do so, data was mainly collected from secondary sources, like books, articles, reports, newspapers and research outputs. Qualitative data analysis, document analysis and interpretation were employed. The findings show that the Commission is marred by political influences, less accessibility, limited awareness of people towards human rights, poor culture of respect for human rights, lack of democratic tradition and good governance, weak institutions like the media and the tighten rule governs civil societies, are among the major hurdles limiting the effectiveness of the Commission. Ethiopia's member of different conventions for human rights like, CCPR, ICESCR, ICERD, CEDAW, CRC and the establishment of the local civil society (EHRCO), though not free from impairments from the ruling party, can be mentioned as some prospects if they are used for better outcomes.
\end{abstract}

Keywords: Human Rights, Promotion, Protection, Challenges, HRCE

DOI: $10.7176 / \mathrm{DCS} / 10-6-05$

Publication date:June $30^{\text {th }} 2020$

\subsection{Introduction}

Since April 2018 and before, as a result of inter-communal conflict in the Somali, Oromia, Amhara and the SNNPR (Southern Nations, Nationalities and Peoples' Region), more than 2.3 million people across Ethiopia are displaced and suffered with grave human right violations (World Vision, 2018; Center for International Human Rights Law and Advocacy, 2018). It makes Ethiopia as the leading country in the world with large number of internally displaced people and the attention of many international humanitarian organizations (IDMC, 2018).

The obligation to protect, promote and ensure the enjoyment of human rights is the prime responsibility of states. It includes among other things, the obligation to take pro-active measures to ensure that human rights are protected, providing effective remedies for persons whose rights are violated, as well as measures against violating the rights of persons within its territory and the like. The establishment of the UN in 1945 in general and UDHR in 1948 with its different international conventions in particular gave rise to the codification and promotion of human rights in the constitution of democratic states across the world (OHCHR, 2010).

Averting human right violations and ensuring its protection and promotion is one of the challenging tasks today. The ample evidences which shows human right violations committed today indicates the reminder of tasks to be done. Over time, the United Nations has employed various tools and strategies to protect and promote human rights and empower the capacity of states, like technical cooperation activities, education and development of publications (Mohammed, 2006; Lamessa, n.d).

However, it is not to mean that the State is the only agent to defend and work for the promotion and consolidation of the protection of human rights. In addition to the State, strong political parties, independent media, civil societies, strong social capital and NGOs (if allowed to function) are vital for protecting human rights. The tendency of governments to allow such organs to involve in human rights is also another issue to be raised here. The objective of this paper is to review the challenges facing EHRC in its role of promoting and protecting human rights in the country. It will also give attention for the prospects in the area.

\subsection{Overview of Human Rights in Ethiopia}

Human rights are natural rights which are given for everybody by virtue of human. They are given for every single human being to enjoy his or her human rights without distinction as to race, color, sex, language, religion, political or other opinion, national or social origin, property, birth or other status. They are expressed in treaties, customary international law, bodies of principles and other sources of law. Human rights law places an obligation on States to act in a particular way and prohibits States from engaging in specified activities. However, the law does not establish human rights. Treaties and other sources of law generally serve to protect formally the rights of individuals and groups against actions or abandonment of actions by Governments which interfere with the 
enjoyment of their human rights (OHCHR, 2017).

Some of the most important characteristics of human rights enshrined in UDHR (1948) include: universality, meaning that they are applied equally and without discrimination to all people; inalienable, in that no one can have his or her human rights taken away other than in specific situations; indivisible, interrelated and interdependent, innate and inborn rights. In practice, the violation of one right will often affect the respect of several other rights. All human rights should therefore be seen as having equal importance and of being equally essential to respect for the dignity and worth of every human being.

During state of emergency, however, states may take permitted derogations over some human rights. Nonderogatory rights - may never be suspended or restricted even in situations of war and armed conflict, like the right to life, freedom from torture, freedom from enslavement or servitude and freedom of thought, conscience and religion. In addition, in times of armed conflict where humanitarian law applies, human rights law continues to afford protection (OHCHR, 2010).

Ethiopia since the beginning of 2016 was under the state of emergency for several months. Human Rights Watch World Report (2017) revealed that the October 2016 of Ethiopian six-month state of emergency following government crackdowns in the Oromia region killed at least 500 people in largely non-violent protests during the past year and 1,600 were arrested. Human Rights Watch received unconfirmed reports of unlawful killings, mass arrests, and looting of houses and businesses by security forces. Mobile phone access to the internet was blocked and Addis Standard, one of Ethiopia's few remaining independent publications, stopped publishing its print edition due to state of emergency restrictions. Ethiopia detains scores of opposition leaders, journalists, and dissenters under its overbroad counterterrorism law of 2009 (Lamessa, n.d). Members of Patriotic Ginbot-7, OLF, OFC, Temesgen Dessalegn (an editor of a weekly newspaper, feteh) are some examples of the detainees.

In Ethiopian constitution of FDRE, 1995 civil and political rights are enshrined but with different nomenclature "democratic rights" as if they are not natural and the result of the democratic process of the incumbent government and mainly delivered by the state. Chapter three of this federal constitution explains about these lists of human rights and their application.

Over the past long years since Ethiopia was ruled under undemocratic government, individual human rights and freedoms were not respected. Instead, the Ethiopian people were long victims of wars and subjected to political crises and never-ending conflicts. In effect the Ethiopian Nations, Nationalities and Peoples have faced poverty, backwardness and under-development and, most importantly, oppression. Bitter struggles were made in different parts of the country, which finally resulted in the overthrow of the eras of dictatorship in May 1991 (FDRE, 2013).

The process of building a system of government based on democracy, respect of human rights and rule of law commenced in 1991 different list of human rights (social, economic and political) are also incorporated in the constitution of 1995. In addition, the Ethiopian government is exerting constant effort to ensure respect and to promote the international principles of human rights. But, still it is not free from problems; the government of Ethiopia is accused of different human rights violations. For example the congress of USA in its HR 128 passed in 2018 calls the Ethiopian government to lift the state of emergency, release all activists, journalists, and opposition figures, allow an independent human rights examination and to encourage inclusive governance in the country. Amnesty international (2017/2018) has also reported that the government of Ethiopia rejects call for independent and impartial investigation in to human rights violations committed in the context of protests. The government failed to bring to justice the possible perpetrators. Mass killings, identity questions, ethnic conflicts and political rivalries continue.

\subsection{Conceptualizing Promotion and Protection of Human Rights}

Some literature used promotion and protection of human rights interchangeably. But the two concepts are different and this section explains these concepts. Seble in her MA thesis (2011) described that promoting human rights, which primarily possible through the media is a vital means to ensure their protection and respect. The media is playing an indispensable role in disseminating any type of relevant information as to the task of promoting human rights. And that is why many of the beliefs of people are believed to be the result of the mainstream media; some say this as the power of the 'age of information. To this extent the promotion task of human rights is possible through awareness creation programs by the UN, publications, sanctions and others implemented not only by the UN but also those states who signed the UN charter, including Ethiopia. Since these countries are formally pledged themselves to promote and protect these right without any distinction as to race, sex, language, religion or other status.

Promotion is the base for defending human rights violations, as those who have awareness about their rights defend it from violation than those who do not have awareness. Hence, people should be nurtured formally in either training or education about their rights. The role of informal education through socialization and interactions will not be considered to have raised the understanding level of individuals about their human rights. Explicitly speaking government should do more in the media, school curriculums, in delivering trainings to strengthen the task of promotion than let the people learn from socialization. The understanding level of people about their human 
rights is varied not only from rural to urban, but also individuals from similar sections of the society will not have the same level of consciousness to exercise and or defend their rights.

Protection of human rights is also another mechanism to maintain the status of rights which is defined by the USAID as;

"actions or programming aimed at preventing or avoiding rights violations by the state, such as: protection of human rights defenders, increasing the capacity of vulnerable populations (victims of torture or war trauma, people with disabilities, indigenous or tribal peoples, labor activists, detainees, women and children) to defend their rights and advocate for themselves, atrocity prevention, aimed at preventing attacks on vulnerable or marginalized populations and Efforts to stop human trafficking and protect its victims" (USIAD, 2017).

\subsection{The Structure and Organization of Human Rights Commission of Ethiopian}

The Ethiopian government in its constitution of 1995 (Article 55) lists the powers and functions of the House of Peoples' Representatives (HPR) to establish a Human Rights Commission and determine by law its powers and functions (sub article 14) and the institution of the Ombudsman, and select and appoint its members (sub article 15) mainly for the purpose of promotion and protection of human rights. In line with this legal document, the institutions of the ombudsman and the Human Rights Commission were established in 2000 (FDRE, 1995). This section highlights the objectives and the functions of the Human Right Commission of Ethiopia.

HPR, as per the powers given to it by the constitution of 1995 established the Ethiopian Human Rights Commission. The objective of the Commission is to educate the public about human rights and make sure that they are protected, respected and fully enforced as well as to have the necessary measure taken where they are found to have been violated. In addition, the Commission has a power and a duty to ensure the enforcement and respect national and international of human rights law in the country (FDRE, Proclamation No. 210/2000). Monitoring and supervising the countries' human rights situation, legislative review, assessment of its functions in promoting and protecting human right violations are also the responsibilities of this organ.

In addition, the Commission shall have full powers to receive and investigate all complaints on human rights violations made against any person, save cases brought before the House, the House of the Federation, Regional Council or before the courts of law, at any level. It shows the independence of the commission and how much power is given to it to enforce and investigate such rights and freedoms before the law of the state.

\subsection{Does EHRC Really Discharge its Responsibilities?}

It is demonstrable that, most of the time the EHRC rejects different complains brought to it (Mohammed, 2006). Though, the causes of rejections are different, as Mohammed identify, the reasons for the rejection of the bulk of complaints are varied, but the very crucial issue is that, the Commission seems to avoid politically sensitive issues, such as the ones relating to forced eviction and political matter. For instance, in the Gambella case and the Gura Farda case (human right violations as a result of forced displacement and ethnic eviction respectively), the commission disclaim jurisdiction and rejected the cases (Mohammed, 2009).

The Commission, to some extent assists the media in its effort in the promotion of human rights as Seble (2011) pointed out. At the same time, it fulfills its obligation as a human rights advocate by spreading the massage of human rights across the country. However, compared to the seriousness of the problem of violations of human rights by the government and the responsibility of the organizations, it is difficult to assert that the commission is playing the expected roles. At present, Societies and Charities are not active participants on human rights advocacy which makes this organization the only organ with the power and capacity of engaging in human rights promotion while there are a wide range of human rights violations by government security forces under the so called "command post". The 2009 proclamation which tightened civil societies and charities not to involve in political matters lays the protection of human rights merely on the hand of the commission. Taking these in to account, this single organization faced with a number of challenges in its role of defending human rights. Some of them are explained below.

\subsection{Challenges of EHRC in Promotion and Protection of Human Rights}

EHRC is established by the government as one of the independent organ to protect human rights in the country. However, it is faced with a number of critical challenges which affect its independence and not to discharge its roles properly and with the expected rate. Mohammed (2009) summarized the challenges marred the EHRC as Lack of democratic tradition and good governance, poor culture of respect for human rights, weak institutions, and financial constraints. The 2011 IDLO (International Development Law Organization) mid-term review shows that EHRC faces many critical challenges due to the political influence which negatively affects its independence, little experience, and limited staff capacity. The challenges may be grouped as internal and external. Internal problems are those related to the extent of autonomy exercised by the commission and its accessibility, legal and practical experiences towards the protection of human rights. External problems are those problems related to clients, like the media, government and the people. 


\section{Internal Challenges Faced by EHRC}

$>$ The question of autonomous/independence of the commission: As Lemesa (n.d) concludes, "the opposition parties and different human rights activists argued that, the government establishes the EHRC only to rebuff criticism of international community". They substantiate their arguments by invoking the Background records of human rights violations that suggests the Ethiopian government was not serious about establishing this Commission. It set up this commission to improve the country's reputation and as an answer to the critics. It means the commission is not free from the influence of politics (high intervention from the legislative and executive branch though it established as an independent organ.

$>$ Inaccessibility and limited awareness of the people about human rights: EHRC is far from accessibility to vulnerable section of community, because there is no "fast track complaint procedure" in especial way for the most vulnerable. It is also physically not accessible to public as its set up is only in certain areas. For instance, the commission has set up only at some branches such as Hawassa, Bahr Dar, Mekele, Gambella, Jijiga, Jimma and some other regional towns. Zonal and district level areas are not getting access from the Commission. The working language of the commission which is Amharic is becoming another problem which did not recognize the diversity though the proclamation (Article.23). Among other challenges, lack of awareness of the rights of persons under detention has to some extent hindered the elimination of violations of the prohibitions (UN General Assembly, 2009).

\section{External challenges of EHRC}

External to the structure and organization of EHRC, there are also challenges attributed to influence the task of protection and promotion of human rights. These include:

$>$ Lack of strong and independent media: Since the media was under the complete control of the government (censorship) during the Imperial, Derge and EPRDF regimes, it does not play its expected roles (Seble, 2011). The Ethiopian government has long committed abuses against media professionals, including harassment and intimidation of journalists, trumped-up prosecutions of journalists under the antiterrorism law, and harassment of sources, printers, publishers, and others (Human Rights Watch, 2016). Reporters without Borders' (2017) cited in the Center for International Human Rights Law and Advocacy (2018) World Press Freedom Index ranks Ethiopia 150 out of 180 countries. In connection to this the incumbent government is blocking the internet repeatedly, arresting journalists and party leaders who defend human rights, distributing false information and hate speeches, denying access to information for journalists and media outlets. A remarkable example for the latter is the 2018 case of displacement of the Gedeo people by the Oromos (World Vision, 2018; IOM, 2018) but denied coverage by both public and private Medias then exposed by activists.

$>$ Government as a source of the problem: the government is accused for compromising constitutional rights like freedom of opinion, expression, and the press as well as the right of the public to seek, receive and impart information. The reports of international human right institutions like the Amnesty International, Human Rights Watch and other institutions shows that there is continual and cruel threat of human rights in the country, especially in the year (2016/2017). Peaceful demonstrations in different parts of the country were changed to bloodshed between the non-armed civil and the government security forces.

$>$ Limitation of government to safeguard socio-economic rights: The Ethiopian government forced rural farmers and pastoralists into service-deprived villages to make room for agricultural megaprojects (Human Rights Watch World Report, 2017). Land grabbing by local and foreign investors in different parts of the country is an indication of the hitherto development. The type of development without consulting the beneficiaries and little attention for environment mainly to achieve the goals of FDI (Foreign Direct Investment) resulted in expel of the indigenous people from their villages.

$>$ Low social capital and no interest on political issues: Social and community ties are key components of the concept of social capital, which is defined as the social networks and interactions that motivate trust among citizens. Individuals with high levels of social capital tend to be volunteers in their communities and get together more frequently with friends and neighbors. They are also more likely to trust or to think kindly of others (Samson, 2014). The current Ethiopian people seem afraid "politics like fire." And this is thought to be as the result of harsh measurements taken by government even witnessed and encountered during peaceful demonstrations held in different parts across the country these days. There is no ground for political discourse; free speech is derogated by the government and agents of the ruling party. Therefore, it becomes unthinkable for having active political engagement and developed social capital in this regard.

$>$ Absence of strong civil societies: the 2009 proclamation of charities and societies in Ethiopia point out activities of charities provided that only Ethiopian Charities and Societies are allowed to participate in the advancement of human and democratic rights. Accordingly, only Ethiopian Charities and Societies can engage in the promotion of equality of nations, nationalities and peoples and that of gender and 
religion, the promotion of the rights of persons with disabilities and children's rights, the promotion of conflict resolution or reconciliation and the promotion of the efficiency of the justice or the law enforcement services, with strict source of fund $90 \%$ of the total budget is generated locally. It denies Ethiopian people the experiences of foreign civil societies on the important matters of democracy, human rights, gender equality and others (Amnesty International, 2012: Ashagrie, 2012: Clark, 2000 and Mercer, 2002).

\subsection{What are the Prospects of EHRC?}

Ethiopia becomes a democratic state in the beginning of 1990s and adopted the federal Constitution with lists of all human and political rights appeared in the UDHR. It can be a guideline for the issue of human rights at least in principle in the country. The national human rights Action Plan (2013-2015) which is established for the purpose of ensuring the full implementation of fundamental and democratic rights guaranteed under the Constitution the primary beneficiaries being the Ethiopian people. How this was implemented and its achievements in fact are the source of another discussion and debate. The move in establishing national human rights commission and the institution of ombudsman (which are autonomous at least in a paper) is also another prospect to be mentioned.

Besides these, Ethiopia is a member to the International Covenant on Civil and Political Rights (ICCPR) in 1993, International Covenant on Economic, Social and Cultural Rights (ICESCR), International Convention on the Elimination of All Forms of Racial Discrimination (ICERD), Convention on the Elimination of All Forms of Discrimination Against Women (CEDAW), Convention on the Rights of the Child (CRC), African Charter on Human and People's Rights.

Although it is one and highly influenced by the ruling party, EHRCO (Ethiopian Human Rights Council) as a local non-governmental, non-profit organization can be mentioned as an opportunity as far as the issue of promotion and protection of human rights is concerned. The hostile attitude of the Government which sometimes seems to label the institution as an opposition party rather than a simple civil society organization that is established in accordance to the laws of the land and operating accordingly had been a formidable challenge (EHRCO, 2016).

\subsection{Concluding Remarks}

To sum up, though the task of promotion and protection, especially the latter, is explicitly given to States: it needs active engagement from civil societies, individuals, and activists, regional and international human right institutions. Unless and otherwise these actors are cooperating, it is difficult to expect that government alone can effectively protect human rights. The problem of violation of human rights and mistreatments are worse in countries of the so called newly democratic countries where most of them are from the third world countries, including Ethiopia.

EHRC is challenged by a number of legal and autonomy problems from the side of the government though it is established as an independent organ. It, therefore, cannot play the desired role of protecting human right violations and exposing allegations. The government should therefore empower the Commission by ensuring its independence and autonomy by fulfilling the legal gabs exist and abstain from interfering in the activities of the Commission.

In addition, the government of Ethiopia should revise the proclamation for charities and civil societies of 2009 , so that experienced foreign civil societies will engage in the promotion of human rights. It should also strengthen local NGOs to work on the areas of human rights in particular and other political matters in general.

\section{References}

Amnesty International (2012). Ethiopia: Human rights work crippled by restrictive law. Available at https://www.amnesty.org. (Accessed date, 02/04/2017).

Ashagrie G. Abdi (2012). The Ethiopian Civil Society Law in Light of the Principle of the Best Interest of the Child. The Interdisciplinary Journal of Human Rights (Vol. 7: 1).

Clark J. (2000). Civil Society, NGOs, and 1 Development in Ethiopia. A Snapshot View. Netherlands.

Center for International Human Rights Law and Advocacy (2018). Divide, Develop and Rule: Human Right Violations in Ethiopia. University of Wyoming, USA.

Federal Democratic Republic of Ethiopia (2013). National Human Rights Action Plan 2013-2015. Addis Ababa. (1995).The Constitution of the Federal Democratic Republic of Ethiopia. Addis Ababa.

(2000). Proclamation No. 211/2000. Institution of the Ombudsman Establishment Proclamation

Federal Negarit Gazeta $6^{\text {th }}$ Year No. 40 Addis Ababa - 4th July, 2000.

(2000). Proclamation No. 210/2000. Ethiopian Human Rights Commission Establishment

Proclamation. Federal Negarit Gazeta $6^{\text {th }}$ Year No. 41 Addis Ababa $-4^{\text {th }}$ July, 2000.

(2009). Proclamation No. 621/2009. Proclamation to Provide for the Registration and Regulation of

Charities and Societies. Federal Negarit Gazeta 15 ${ }^{\text {th }}$ Year No.25 Addis Ababa $13^{\text {th }}$ February, 2009.

EHRCO (Ethiopian Human Rights Council). HRCO at 25: We Renew Our Vows to Strive for the Realization of 
Real Democracy, Rule of Law and the Observance of Human Rights. Available at https://ehrco.org. (Accessed date 05/04/2017).

Human Rights Watch World Report (2017). Events of 2016. USA.

Human Rights Watch (2016). Legal Analysis of Ethiopia's State of Emergency, available at https://www.hrw.org. (Accessed date, 02/04/1207).

Internal Displacement Monitoring Centre (IDMC). 2018. Ethiopia tops global list of highest internal displacement in 2018. Available at https://reliefweb.int/report/ethiopia, on 12/03/2020.

IOM (2018). IOM Identifies 970,000 Displaced People in Ethiopia's Gedeo, West Guji Since April 2018. Available at https://reliefweb.int/report/ethiopia/ accessed on 12/11/2019.

IDLO (International Development Law Organization) (2011). Mid-term review, Enhancing the Functional Protection of Human Rights in Ethiopia Project (UDF-ETH-08-227).

Lamessa Gudeta (n.d). The roles and function of Ethiopian Human Rights Commission. Critical Analysis in Promotion of Human Rights. Available at http://independent.academia.edu/ (Accessed date: 05/04/2017).

Mercer, C. (2002) NGOs, Civil Society and Democratization: A Critical Review of the Literature. Progress in Development Studies pp. 5-22. Department of Geography, University of Leicester, UK.

Mohammed Abdo (2006). The Ethiopian Human Rights Commission: Challenges Confronting Its Effective Functioning', Chinese Year Book of Human Rights, Vol. 4, 2006.

Mohammed Abdo (2009). The Ethiopian Human Rights Commission and its Contribution in the Protection of Human Rights and Building of Good Governance: Challenges and Prospects. Institute of Federalism and Legal studies, ESCU. Ghent University, Belgium.

OHCHR (2010). Office of the High Commissioner for Human Rights United Nations Staff College Project Human Rights: A Basic Handbook for UN Staff, Geneva, Switzerland.

OHCHR: http://www.ohchr.org/EN/Issues/Pages/What are Human Rights.( Accessed date, 01/04/2107).

Samson Kassahun (2014). Social Capital and Trust in Slum Areas: the Case of Addis Ababa, Ethiopia. Urban Forum (2015) 26:171-185, Springer Science + Business Media Dordrecht.

Seble Teweldebirhan (2011). The Role of Media in the Promotion of Human Rights in Ethiopia. A Thesis Submitted In the Partial Fulfillment of the Requirement for the Degree Of Masters of Laws in Human Rights Law, Faculty of Law, Addis Ababa University (Unpublished).

UN General Assembly (2009). Ethiopia's National Report under the Universal Periodic Review Mechanism. Human Rights Council Working Group on the Universal Periodic Review. Sixth session. Geneva.

USIAD, available at https:/www.usaid.gov/what-we-do/democracy-human-rights-and governance/protectinghuman-rights. (Accessed date 01/04/2017).

World Vision (2018). Response Plan to Internal Displacement around Gedeo (SNNPR) and West Guji (Oromia) Zonesa 